\title{
Pengaruh financial distress dan leverage terhadap konservatisme akuntansi
}

\author{
Susi Sulastri * Yane Devi Anna ${ }^{* *}$ \\ * STIE AKUITAS BANDUNG, susisulastri427@gmail.com, Bandung, Indonesia \\ ** STIE AKUITAS BANDUNG, yane.devi@ekuitas.ac.id, Bandung , Indonesia
}

\section{ARTICLE INFO}

Article history:

Received 10 April 2018

Received I Revised 03

Agustus 2018

Accepted 08 Agustus 2018

Keywords:

Company Size,

Quality of KAP,

Profitability, the

accuracy of financial

statement submission.

\section{A B S T R A C T}

The financial statements are a description of a company's performance. Management is given the flexibility in choosing accounting methods that will be used one of them by applying accounting conservatism. The purpose of this study is to determine the effect of financial distress and leverage on accounting conservatism. The methods used in this study are descriptive and verification methods. The population of this study is mining companies listed on the Indonesia Stock Exchange in 2012-2016.

The results of this study indicate that partially financial distress have a significant on accounting conservatism and the leverage have a significant on accounting conservatism. Simultaneously shows that financial distress and the leverage have a significant on accounting conservatism.

Laporan keuangan adalah deskripsi kinerja perusahaan. Manajemen diberikan fleksibilitas dalam memilih metode akuntansi yang akan digunakan salah satunya dengan menerapkan konservatisme akuntansi. Tujuan penelitian ini adalah untuk mengetahui pengaruh financial distress dan leverage terhadap konservatisme akuntansi. Metode yang digunakan dalam penelitian ini adalah metode deskriptif dan verifikatif. Populasi penelitian ini adalah perusahaan pertambangan yang terdaftar di Bursa Efek Indonesia pada tahun 2012-2016.

Hasil penelitian ini menunjukkan bahwa financial distress secara parsial signifikan terhadap konservatisme akuntansi dan leverage signifikan terhadap konservatisme akuntansi. Secara bersama - sama keduanya menunjukkan bahwa financial distress dan leverage signifikan terhadap konservatisme akuntansi.

E-mail address: susisulastri427@gmail.com

Peer review under responsibility of Akuisisi : Accounting Journal. 2477-2984.

http://dx.doi.org/10.24217 


\section{PENDAHULUAN}

Standar akuntansi keuangan memberikan kebebasan bagi perusahan untuk memilih metode maupun estimasi akuntansi yang digunakan dalam penyusunan laporan keuangan. Perusahaan dapat memilih metode akuntansi yang sesuai dengan kondisi perusahaan tersebut sehingga perusahaan dapat lebih fleksibel dalam menyesuaikan metode akuntansi yang akan digunakan dengan kondisi perekonomian yang dialami perusahaan. Kondisi perekonomian di masa mendatang dipenuhi dengan ketidakpastian sehingga perusahaan perlu berhati-hati dalam memilih metode yang akan digunakan (Risdiyani dan Kusmuriyanto, 2015).

Prinsip konservatisme merupakan prinsip kehati-hatian terhadap suatu keadaan yang tidak pasti untuk menghindari optimisme berlebihan dari manajemen dan pemilik perusahaan. Konservatisme memiliki kaidah pokok yaitu tidak boleh mengakui laba sebelum terjadi, tetapi harus mengakui kerugian yang sangat mungkin terjadi. Selain itu, apabila dihadapkan pada dua atau lebih pilihan metode akuntansi, maka akuntan harus memilih metode yang paling tidak menguntungkan bagi perusahaan (Dewi dan Suryanawa, 2010).

Konservatisme merupakan konsep akuntansi yang kontroversial, banyak pertentangan tentang penggunaan konservatisme dalam penyusunan laporan keuangan. Penggunaan konservatisme dapat dianggap bermanfaat yaitu untuk mengantisipasi ketidakpastian yang dapat dialami perusahaan di masa mendatang, namun di sisi lain penggunaan konservatisme dianggap tidak mencerminkan kondisi keuangan perusahaan yang sebenarnya sehingga dapat mempengaruhi kualitas laporan keuangan perusahaan. Konservatisme akuntansi digunakan untuk mengurangi risiko dan penggunaan optimisme yang berlebihan yang dilakukan oleh manajer dan pemilik perusahaan. Penggunaan konservatisme tidak dapat digunakan secara berlebihan karena dapat mengakibatkan kesalahan dalam perhitungan laba atau rugi periodik perusahaan, hal tersebut tidak mencerminkan kondisi perusahaan yang sebenarnya. Informasi yang tidak mencerminkan kondisi suatu perusahaan yang sebenarnya akan mengakibatkan keraguan dalam kualitas pelaporan dan kualitas laba, hal tersebut dapat menyesatkan pihak pengguna laporan keuangan dalam pengambilan keputusan (Risdiyani dan Kusmuriyanto, 2015).

Skandal keuangan terkait dengan rendahnya prinsip konservatisme akuntansi terjadi pada beberapa perusahaan. Perusahaan elektronik ternama asal Jepang yaitu Toshiba Corporation melakukan penggelembungan laba (overstate) yang mencapai 151,8 miliar yen atau sekitar Rp. 16 triliun. Sedangkan, perusahaan tersebut diperkirakan mencapai kerugian sebesar 550 miliar yen atau setara dengan US\$ 4,5 miliar pada tahun fiskal yang berakhir Maret 2016. Tersiar kabar bahwa para eksekutif perusahaan tersebut kerap menekan bawahannya secara sistematis untuk menaikan laba. Skema ini berlangsung bertahun-tahun dengan tujuan menyembunyikan hasil buruk perusahaan (www.beritasatu.com, 10 Oktober 2017).

Fenomena lainnya yang terkait konservatisme akuntansi juga terjadi di perusahaan pertambangan. Dalam kasus ini Ikatan Karyawan Timah (IKT) pada press release laporan keuangan semester I-2015 yang mengatakan bahwa efisiensi dan strategi yang telah membuahkan kinerja yang positif. Padahal kenyataannya pada semester I-2015 laba operasi rugi sebesar Rp 59 miliar. Selain mengalami penurunan laba, PT Timah juga mencatatkan peningkatan utang hampir 100 persen dibanding 2013. PT Timah (Persero) Tbk diduga memberikan laporan keuangan fiktif pada semester I 2015 lalu. Kegiatan laporan keuangan fiktif ini dilakukan guna menutupi kinerja keuangan PT Timah yang terus mengkhawatirkan. PT Timah sejak tiga tahun belakangan kurang sehat. Ketidakmampuan jajaran Direksi PT Timah keluar dari jerat kerugian telah mengakibatkan penyerahan $80 \%$ wilayah tambang milik PT Timah kepada mitra usaha (www.tambang.co.id, diunduh pada 12 Oktober 2017). 
Ada beberapa faktor dalam menentukan keputusan manajer menggunakan metode konservatif atau tidak. Financial distress (tingkat kesulitan keuangan) dapat diartikan sebagai gejala awal kebangkrutan akibat penurunan kondisi keuangan yang dialami oleh suatu perusahaan. Kondisi keuangan perusahaan yang bermasalah dapat mendorong pemegang saham melakukan penggantian manajer perusahaan, yang kemudian juga dapat menurunkan nilai pasar manajer yang bersangkutan di pasar kerja. Ancaman tersebut dapat mendorong manajer untuk mengatur pola laba akuntansi yang merupakan salah satu tolak ukur kinerja manajer. Sehingga kondisi keuangan perusahaan yang bermasalah dapat mendorong manajer mengatur tingkat konservatisme akuntansi (Setyaningsih, 2008).

Faktor lain yang dapat mempengaruhi konservatisme akuntansi adalah tingkat hutang (leverage). Lo dan Suryanawa (2014) menyatakan jika perusahaan mempunyai hutang tinggi maka kreditur juga mempunyai hak untuk mengetahui dan mengawasi jalannya kegiatan operasional perusahaan, yang mengakibatkan perusahaan menerapkan prinsip kehati-hatian dalam memperoleh laba. Dengan pemberian informasi yang mengakui adanya laba yang rendah dapat membantu mengurangi adanya konflik antara manajer dan pemegang saham, karena manajer berusaha menyampaikan informasi secara jujur dan penuh kehati-hatian (Wijaya, 2017).

\section{METODE}

Penelitian ini merupakan penelitian kuantitatif dengan menggunakan regresi linier berganda dengan data penelitian menggunakan data sekunder.

\subsection{Populasi dan Sampel}

Data sekunder dalam penelitian ini adalah laporan keuangan tahunan perusahaan pertambangan yang terdapat di Bursa Efek Indonesia (BEI) dari tahun 2012 sampai dengan 2016. Pengambilan sampel dengan menggunakan purposive sampling dengan kriteria : perusahaan yang menerbitkan laporan keuangan auditan tahun 2012 - 2016, perusahaan yang menyajikan laporan keuangan dalam mata uang rupiah dan memiliki data yang lengkap terkait dengan variabel-variabel yang digunakan dalam penelitian.

\subsection{Variabel Penelitian dan Pengukuran Variabel}

1. Variabel Independen, Dalam penelitian ini variable independen adalah financial distress dan leverage.

a. Financial distress

Kesulitan keuangan merupakan tahap penurunan kondisi keuangan yang terjadi sebelum terjadinya kebangkrutan ataupun likuidasi (Fahmi, 201:158). Dalam penelitian ini, pengukuran yang digunakan peneliti dalam mengukur financial distress adalah metode analisis kebangkrutan Altman Z-score dalam persamaan 1.

$$
Z^{\prime}=0,717 X_{1}+0,847 X_{2}+3.107 X_{3}+0,42 X_{4}+0,998 X_{5}
$$


$\mathrm{X}_{1}=$ Modal Kerja/Total Aset

$\mathrm{X}_{2}=$ Laba Ditahan/Total Aset

$\mathrm{X}_{3}=$ Laba sebelum Bunga dan Pajak/Total Aset

$\mathrm{X}_{4}=$ Ekuitas pemegang saham/Total Kewajiban

$\mathrm{X}_{5}=$ Penjualan/ Total Asset

b. Leverage

Leverage dapat diukur dengan sejauh mana perusahaan menggunakan pendanaan melalui utang. Leverage dapat diukur dengan menggunakan rasio leverage. Debt to Equity Ratio (DER) dapat diukur dengan rumus sebagai berikut (Kasmir, 2015:157):

$$
\text { Debt to Equity Rasio }=\frac{\text { tocal debt }}{\text { total equity }}
$$

\section{Variabel Dependen}

Konservatisme merupakan suatu prinsip ketika kerugian terjadi maka seluruh kerugian tersebut akan langsung diakui meskipun belum terealisasi, akan tetapi ketika keuntungan terjadi, maka keuntungan yang belum terealisasi tidaklah diakui (Hery, 2015:53). Konservatisme dapat diukur dengan earning/accrual measure menurut Givoly dan Hayn (2002) dalam Savitri (2016:61) yang menyatakan apabila terjadi akrual negatif (laba bersih lebih kecil dari pada arus kas kegiatan operasi) yang konsisten selama beberapa tahun, maka merupakan indikasi diterapkannya konservatisme. Semakin besar akrual negatif yang diperoleh maka semakin konservatif akuntansi yang diterapkan, oleh sebab itu konservatisme menggunakan persamaan 3:

$$
\mathrm{C}_{\mathrm{it}}=\mathrm{NI}_{\mathrm{it}}-\mathrm{CFO}_{\mathrm{it}}
$$

\footnotetext{
Keterangan:

$\mathrm{C}_{\mathrm{it}} \quad=$ Tingkat konservatisme perusahaan I pada waktu $\mathrm{t}$

$\mathrm{NI}_{\mathrm{it}}$ = Laba bersih sebelum extra ordinary item dikurangkan depresiasi dan amortisasi

$\mathrm{CFO}_{\mathrm{it}}=$ Arus kas dari kegiatan operasi
}

\subsection{Pengembangan Hipotesis}

\section{Pengaruh financial distress terhadap konservatisme akuntansi}

Kesulitan keuangan merupakan tahap penurunan kondisi keuangan yang terjadi sebelum terjadinya kebangkrutan ataupun likuidasi. Financial distress dimulai dengan ketidakmampuan memenuhi kewajiban-kewajibannya, terutama kewajiban yang bersifat jangka pendek termasuk kewajiban likuiditas, dan juga termasuk kewajiban dalam kategori solvabilitas (Fahmi, 2013:158). 
Teori signaling menjelaskan bahwa pemberian sinyal dilakukan oleh manajer untuk mengurangi asimetri informasi. Manajer memberikan informasi melalui laporan keuangan bahwa mereka menerapkan kebijakan akuntansi konservatisme yang menghasilkan laba lebih berkualitas karena prinsip ini mencegah perusahaan melakukan tindakan membesar-besarkan laba dan membantu pengguna laporan keuangan dengan menyajikan laba dan aktiva yang tidak overstate (Fala dan Nugroho, 2012).

Dalam kondisi keuangan yang bermasalah, manajer cenderung menerapkan konservatisme akuntansi untuk mengurangi konflik antara investor dan kreditor. Konservatisme merupakan prinsip kehati-hatian, maka dengan adanya kesulitan keuangan mendorong perusahaan akan lebih berhati-hati dalam menghadapi lingkungan yang tidak pasti. Dengan demikian, financial distress perusahaan semakin tinggi akan mendorong manajer untuk menaikan tingkat konservatisme akuntansi, dan sebaliknya jika financial distress rendah manajer akan menurunkan tingkat konservatisme akuntansi (Suryadari dan Priyanto, 2012).

Financial distress yang tinggi tercermin dari nilai Z-Score yang semakin rendah dan financial distress yang rendah tercermin dari nilai Z Score yang semakin tinggi. Sementara tingkat konservatisme yang tinggi tercermin dari nilai $C_{\text {it }}$ yang semakin negatif dan sebaliknya. Sehingga ketika perusahaan mengalami financial distress yang tinggi maka perusahaan akan semakin konservatif dan begitupun pula ketika perusahaan memiliki financial distress yang rendah maka perusahaan cenderung tidak konservatif.

Hal ini didukung penelitian-penelitian yang dilakukan oleh Pramudita (2012), Suryadani dan Priyanto (2012), Rizkyka dkk.(2016), Tista dkk. (2017), dan Hakim (2017) mengatakan bahwa financial distress berpengaruh terhadap konservatisme akuntansi.

$\mathrm{H}_{1}$ : Financial distress berpengaruh terhadap konservatisme akuntansi

\section{Pengaruh Leverage terhadap Konservatisme Akuntansi}

Hutang adalah semua kewajiban keuangan perusahaan kepada pihak lain yang belum terpenuhi, di mana hutang ini merupakan sumber dana atau modal perusahaan yang berasal dari kreditur (Munawir, 2010:18). Tingkat hutang dapat diidentifikasi menggunakan rasio leverage. Rasio leverage merupakan rasio yang mengukur seberapa jauh perusahaan dibiayai oleh kewajiban atau pihak luar dengan kemampuan perusahaan yang digambarkan oleh ekuitas. Setiap penggunaan utang oleh perusahaan akan berpengaruh terhadap rasio dan pengembalian. Rasio ini dapat digunakan untuk melihat seberapa risiko keuangan perusahaan (Harahap, 2015:306).

Leverage yang tinggi akan membuat perusahaan lebih berhati-hati, karena leverage yang tinggi menjadi ancaman bagi kelangsungan hidup perusahaan. Pada perusahaan yang memiliki leverage yang lebih tinggi, kreditor mempunyai hak lebih besar untuk mengetahui dan mengawasi penyelenggaraan operasi dan akuntansi perusahaan, manajer mengalami kesulitan untuk menyembunyikan informasi dari kreditor. Kreditor berkepentingan terhadap distribusi aset bersih dan laba yang lebih rendah kepada manajer dan pemegang saham sehingga kreditor cenderung meminta manajer untuk menyelenggarakan akuntansi konservatif (Pramudita, 2012).

Perusahaan akan lebih berhati-hati karena dengan leverage yang tinggi akan menjadi ancaman bagi kelangsungan hidup perusahaan. Pemberian informasi yang mengakui adanya laba yang rendah dapat membantu mengurangi adanya konflik antara manajer dan pemegang saham, karena manajer berusaha menyampaikan informasi secara jujur dengan penuh kehati-hatian (Wijaya dkk, 2017). 
Hal ini didukung penelitian-penelitian yang dilakukan oleh Pramudita (2012), Dewi dan Suryanawa (2014), Wijaya dkk. (2017), dan putri (2017) mengatakan bahwa leverage (leverage) berpengaruh terhadap konservatisme akuntansi.

$\mathrm{H}_{2}$ : Leverage berpengaruh terhadap konservatisme akuntansi

\section{HASIL DAN PEMBAHASAN}

\subsection{Uji Asumsi Klasik}

\section{a. Uji Normalitas Data}

Hasil pengujian dari one-sample kolmogorov smirnov menunjukan bahwa nilai signifikasi (Asymp.Sig 2-tailed) sebesar 0,92 artinya nilai signifikasi lebih dari $0,05(0,92>0,05)$ artinya nilai residual tersebut normal.

b. Uji Autokorelasi

Hasil pengujian dari one-sample kolmogorov smirnov di atas menunjukan bahwa nilai signifikasi (Asymp.Sig 2-tailed) sebesar 0,92 artinya nilai signifikasi lebih dari $0,05(0,92>0,05)$ artinya nilai residual tersebut normal.

c. Uji Multikolonieritas

Hasil pengujian menunjukkan bahwa nilai VIF pada kedua variabel diatas lebih kecil dari 10, yaitu financial distress sebesar 4,281 dan leverage 4,281. Selain itu, nilai tolerance kedua variabel tersebut lebih besar dari 0,10, yaitu financial distress 0,234 dan leverage 0,234. Dengan demikian dapat disimpulkan bahwa diantara kedua variabel independen tersebut tidak terjadi multikolerasi.

d. Uji Heteroskedastisitas

Hasil pengujian menunjukan hasil bahwa berdasarkan grafik scatterplot bahwa titik - titik menyebar secara acak serta tersebar baik diatas maupun dibawah angka 0 pada sumbu Y. Hal ini dapat disimpulkan bahwa tidak terjadi heteroskedastisitas pada model regresi. 


\subsection{Uji Hipotesis}

\section{Koofisien Determinasi}

Nilai koefisien determinasi yang diperoleh melalui hasil pengolahan menggunakan disajikan pada tabel berikut :

\section{Tabel 1}

\section{Analisis Koefisien Determinasi}

Model Summary ${ }^{b}$

\begin{tabular}{|l|l|l|l|l|}
\hline Model & R & R Square & Adjusted R Square & Std. Error of the Estimate \\
\hline 1 &, $719^{\mathrm{a}}$ &, 517 &, 494 & 1122125107633,67100 \\
\hline
\end{tabular}

a. Predictors: (Constant), Leverage, Financial distress

b. Dependent Variable: Konservatisme Akuntansi

Pada tabel 1 di atas dapat dilihat bahwa nilai R-square $(0,517)$ yang dikenal dengan istilah koefisien determinasi (KD) yang dihitung dari mengkuadratkan koefisien korelasi, maka dapat disimpulkan bahwa variabel Y dipengaruhi oleh variabel X sebesar 51,7\% sedangkan sisanya 48,3\% dipengaruhi oleh faktor lain yang tidak dijelaskan dalam penelitian ini.

\section{Uji Parsial}

Nilai statistik uji t yang digunakan pada pengujian secara parsial dapat dilihat pada tabel 2 sebagai berikut:

Tabel 2

Pengujian Hipotesis Parsial (Uji t)

\begin{tabular}{|c|c|c|c|c|c|c|c|c|}
\hline \multicolumn{9}{|c|}{ Coefficients $^{a}$} \\
\hline \multirow{2}{*}{\multicolumn{2}{|c|}{ Model }} & \multicolumn{2}{|c|}{$\begin{array}{l}\text { Unstandardized } \\
\text { Coefficients }\end{array}$} & \multirow{2}{*}{$\begin{array}{l}\begin{array}{l}\text { Standardized } \\
\text { Coefficients }\end{array} \\
\text { Beta }\end{array}$} & \multirow{2}{*}{$\mathrm{T}$} & \multirow{2}{*}{ Sig. } & \multicolumn{2}{|c|}{ Collinearity Statistics } \\
\hline & & $\mathrm{B}$ & Std. Error & & & & Tolerance & VIF \\
\hline \multirow[t]{3}{*}{1} & (Constant) & $-3,7 \mathrm{E}+12$ & $9,2 \mathrm{E}+11$ & & $-4,000$ & 0,000 & & \\
\hline & $\begin{array}{l}\text { Financial } \\
\text { distress }\end{array}$ & $1,93 \mathrm{E}+12$ & $3,35 \mathrm{E}+11$ & 1,275 & 5,746 & 0,000 & 0,234 & 4,281 \\
\hline & Leverage & $1,23 \mathrm{E}+12$ & $3,67 \mathrm{E}+11$ & 0,746 & 3,362 & 0,002 & 0,234 & 4,281 \\
\hline
\end{tabular}

a. Dependent Variable: Konservatisme Akuntansi 
Hasil dari uji statistik diperoleh bahwa nilai signifikansi 0,000 , nilainya lebih kecil dari signifikasi $0,05(0,000<0,05)$ artinya $\mathrm{H}_{0}$ ditolak. Berdasarkan hasil pengujian dapat disimpulkan bahwa dengan derajat kepercayaan 95\%, secara parsial financial distress berpengaruh signifikan terhadap konservatisme akuntansi dan leverage berpengaruh signifikan terhadap konservatisme akuntansi.

\section{Uji Simultan}

Hasil perhitungan Uji F dapat dilihat sebagai berikut:

\section{Tabel 3}

\section{Pengujian Hipotesis Simultan (Uji F)}

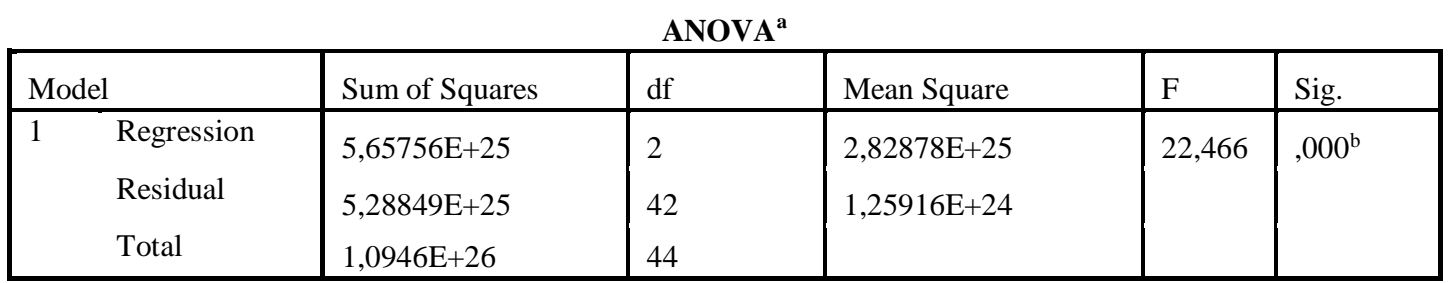

a. Dependent Variable: Konservatisme Akuntansi

b. Predictors: (Constant), Leverage, Financial distress

Dari tabel di atas dapat dilihat dari perbandingan probabilitas dengan tingkat signifikansi sebesar 0,05 dimana probabilitas sebesar 0.000 nilainya lebih kecil dari nilai signifikansi $(0.000<0,05)$ artinya $\mathrm{H}_{3}$ diterima, sehingga dapat disimpulkan bahwa financial distress dan leverage secara simultan berpengaruh signifikan terhadap konservatisme akuntansi.

\subsection{Pembahasan}

\section{Pengaruh financial distress terhadap konservatisme akuntansi}

Berdasarkan hasil perhitungan statistic disimpulkan bahwa financial distress berpengaruh signifikan terhadap konservatisme akuntansi pada perusahaan pertambangan, semakin tinggi financial distress perusahaan maka perusahaan akan semakin konservatif.

Financial distress merupakan tahap penurunan kondisi keuangan yang terjadi sebelum terjadinya kebangkrutan ataupun likuidasi (Fahmi,2013:158). Salah satu faktor yang mempengaruhi financial distress adalah laba. Selain itu, laba juga merupakan salah satu faktor yang mempengaruhi bagaimana cerminan dari penerapan konservatisme akuntansi. Ketika laba kecil, nilai Altman Z-score kecil dan mengindikasikan financial distress meningkat dan juga ketika laba yang kecil maka perusahaan juga mencerminkan penerapan prinsip konservatisme akuntansi yang tinggi, begitupun juga sebaliknya. Konservatisme akuntansi diterapkan ketika kerugian terjadi maka seluruh kerugian tersebut akan langsung diakui meskipun belum terealisasi, akan tetapi ketika keuntungan terjadi, maka keuntungan yang belum terealisasi tidaklah diakui (Hery, 2015:53).

Financial distress perusahaan berpengaruh secara signifikan terhadap konservatisme akuntansi. Dalam kondisi keuangan yang bermasalah, manajer cenderung menerapkan konservatisme akuntansi untuk mengurangi konflik antara investor dan kreditor. Konservatisme merupakan prinsip kehati-hatian, maka dengan adanya kesulitan keuangan mendorong perusahaan akan lebih berhati-hati dalam menghadapi lingkungan yang tidak pasti. Dengan demikian, financial distress perusahaan semakin 
tinggi akan mendorong manajer untuk menaikan tingkat konservatisme akuntansi, dan sebaliknya jika financial distress rendah manajer akan menurunkan tingkat konservatisme akuntansi (Suryadari dan Priyanto, 2012).

\section{Pengaruh leverage terhadap konservatisme akuntansi}

Berdasarkan hasil perhitungan statistik dapat disimpulkan bahwa leverage berpengaruh signifikan terhadap konservatisme akuntansi pada perusahaan pertambangan dan semakin tinggi leverage perusahaan maka perusahaan akan semakin konservatif.

Leverage yang tinggi akan membuat perusahaan lebih berhati-hati, karena leverage yang tinggi menjadi ancaman bagi kelangsungan hidup perusahaan. Pada perusahaan yang memiliki leverage yang lebih tinggi, kreditor mempunyai hak lebih besar untuk mengetahui dan mengawasi penyelenggaraan operasi dan akuntansi perusahaan, manajer mengalami kesulitan untuk menyembunyikan informasi dari kreditor. Kreditor berkepentingan terhadap distribusi aset bersih dan laba yang lebih rendah kepada manajer dan pemegang saham sehingga kreditor cenderung meminta manajer untuk menyelenggarakan akuntansi konservatif (Pramudita, 2012). Semakin besar tingkat rasio debt to equity ratio, maka akan semakin baik kemampuan perusahaan untuk membayar hutangnya. Dengan adanya leverage yang tinggi perusahaan akan lebih berhati-hati dalam menghadapi lingkungan yang penuh ketidakpastian.

Hasil penelitian ini sejalan dengan penelitian yang dilakukan oleh Dewi dan Suryanawa (2014), Kusmuriyanto (2015), Wijaya dkk.(2017) dan Putri (2017) bahwa leverage berpengaruh terhadap konservatisme akuntansi.

\section{KESIMPULAN}

Berdasarkan hasil penelitian dan pembahasan yang telah dijelaskan baik secara parsial maupun simultan bahwa financial distress dan leverage berpengaruh terhadap konservatisme akuntansi pada perusahaan pertambangan.

Penelitian ini masih memiliki keterbatasan dengan jumlah sampel yang terbatas sehingga disarankan untuk melakukan penelitian di industri lain dengan jumlah perusahaan yang lebih banyak. Selain itu untuk penelitian selanjutnya dapat mengembangkan penelitian dengan menggunakan variabel lain yang belum dimasukkan dalam penelitian ini yang memiliki pengaruh terhadap konservatisme akuntansi, seperti: ukuran perusahaan, risiko litigasi, kepemilikan manajerial, intensitas modal dan lainlain.

\section{DAFTAR PUSTAKA}

Belkaoui, A.R. 2011. Accounting Theory: Teori Akuntansi, Jakarta: Salemba Empat.

Darsono, dan Ashari., 2010. Pedoman Praktis Memahami Laporan Keuangan (Tips. Bagi Investor, Direksi, dan Pemegang Saham).

Dewi Lestari dan Suryanawa. 2014. Pengaruh Struktur Kepemilikan Manajerial, Leverage, dan Financial Distress terhadap Konservatisme Akuntansi, ISSN: 2302-8556., Universitas Undaya. 
Fahmi, Irham. 2013. Analisis Laporan Keuangan. Bandung: Alfabeta.

Faturahmi Afina. 2015. Pengaruh Ghrow Opportunities dan Financial Distress terhadap Conservatism Accounting, ISSN: 2460-6561., Universitas Islam Bandung.

Ghozali, Imam. 2013. Aplikasi Analisis Multivariate dengan Program SPSS, Cetakan ke IX. Semarang: Badan Penerbit UNDIP.

Hakim, M.Z. 2017. Determinasi Konservatisme Akuntansi pada Industri Dasar dan Kimia, Competitive, Vol.1 No.1., Universitas Muhamadiyah Tangerang.

Hanafi, M., dan Halim, A. 2012. Analisis Laporan Keuangan, Edisi , Cetakan Kedua, Yogyakarta: UPP Sekolah Tinggi Ilmu Manajemen YKPN.

Harahap, Sofyan Syafri. 2015. Analisis Kritis atas Laporan Keuangan, Edisi 1-10., Jakarta: Rajawali Pers.

Hery. 2015. Analisis Laporan Keuangan, Edisi 1. Yogyakarta: Center For Academic Publishing Services. Ikatan Akuntan Indonesia. 2017. Standar Akuntansi Keuangan, Jakarta: Salemba Empat.

Munawir. (2010).Analisa Laporan Keuangan. Yogyakarta: Liberty.

Pramudita, N. 2012. Pengaruh Financial distress dan Leverage terhadap Konservatisme Akuntansi, Jurnal Ilmiah Mahasiswa Akuntansi, Vol.1 No.2.

Priyanto, R.E., dan Suryadani Erni. 2012. Pengaruh Risiko Litigasi dan Financial distress Perusahaan terhadap Hubungan antara Konflik Kepentingan dan Konservatisme Akuntansi, Jurnal Akuntansi dan Investasi, Vol.12 No.2., hal: 161-174, Fakultas Ekonomi Universitas Muhammadiyah Yogyakarta.

Putri, A.G. 2017. Pengaruh Financial distress, Risiko Litigasi dan Leverage terhadap Konservatisme Akuntansi, JOM Fekon, Vol.4 No.1., Fakultas Ekonomi, Universitas Riau, Pekanbaru.

Quljanah Mifta dan Nuraina Elva. 2017. Pengaruh Growth Opportunities dan Leverage terhadap Konservatisme Akuntansi, e-ISSN: 2337-9723, Universitas PGRI Madiun.

Risdiyadi, F., dan Kusmuriyanto. 2015. Analisis Faktor-Faktor yang Mempengaruhi Penerapan Konservatisme Akuntansi, ISSN:2252-6765., Universitas Negeri Semarang.

Rizkyka Trissa. 2016. Pengaruh Risiko Litigasi dan Financial distress terhadap Konservatisme Akuntansi, ISSN: 2460-6561., Universitas Islam Bandung.

Ross, Stephen A., Randolph W. Westerfield, \& Bradford D. Jordan. 2013. Pengantar Keuangan Perusahaan, Jakarta: Salemba Empat.

Rudianto. 2013. Akuntansi Manajemen Informasi untuk Pengambilan Keputusan Strategis, Jakarta: Erlangga

Savitri, Enni. 2016. Konservatisme Akuntansi. Yogyakarta: Pustaka Sahila.

Schmuck, M. 2013. Financial Distress and Corporate Turnaround. Muenchen: Springer Gabler.

Sekaran, Uma dan Bougie, R. 2017. Metode Penelitian Untuk Bisnis. Edisi 6. Jakarta: Salemba Empat Setyaningsih, H. 2008. Pengaruh Financial distress Perusahaan terhadap Konservatisme Akuntansi, Jurnal Akuntansi dan Investasi, Vol.9 No.1., hal: 91-107.

Subramanyam, K.R dan Wild, JJ. Harsey. 2010. Analisis Laporan Keuangan. Edisi 10. Jakarta: Salemba Empat.

Sugiyono. 2017. Metode Penelitian Bisnis (pendekatan kuantitatif, kualitatif, dan R\&D. Cetakan ke-23, Bandung: Alfabeta.

Suwardjono . 2014. Teori Akuntansi Perekayasaan Pelaporan Keuangan, Edisi Ketiga, Cetakan Kedelapan. Yogyakarta: BPFE-YOGYAKARTA. 
Tista, K.W.N., dan Suryanawa. 2017. Pengaruh Ukuran Perusahaan dan Potensi Kesulitan Keuangan pada Konservatisme Akuntansi dengan Leverage sebagai Pemoderasi, ISSN:2302-8556, Vol.18 No.3., Universitas Undaya.

http://www.beritasatu.com/dunia/292689-skandal-mark-up-laba-perusahaan-ceo-toshiba-mundur. html, diunduh tanggal 10 Oktober 2017

http://www.kompasiana.com/muhammad_cobain/industripertambanganmenyelamatn-indonesia, diunduh pada 12 Oktober 2017

http://www.idx.go.id, diunduh bulan November 2017

http://www.sahamok.com, diunduh bulan November 2017 